\title{
Preventive and Therapeutic Effects Ramulus Mori Extract on Collagen-Induced Arthritis in Mice via Suppression of Inflammatory T Cells
}

\author{
Seong-Soo Roh, ${ }^{a}$ Bu-Il Seo, ${ }^{a}$ Yong-Ung Kim,,${ }^{b, 1}$ Sae-Kwang Ku, ${ }^{c}$ and Young-Bae Seo ${ }^{*} d$ \\ ${ }^{a}$ Department of Herbology, ${ }^{b}$ Department of Korean Internal Medicine and ${ }^{c}$ Department of Histology and Anatomy, College of Oriental \\ Medicine, Daegu Haany University, 290, Yugok-dong, 1, Hanui-daero, Gyeongsan-si, 712-715, Gyeongsangbuk-do, Republic of Korea \\ and ${ }^{d}$ Department of Herbology, College of Oriental Medicine, Daejeon University, 96-3, Yongun-dong, Dong-gu, Daejeon-si, 300-716, \\ Republic of Korea
}

(Received May 19, 2010; Accepted January 5, 2011)

\begin{abstract}
We researched the preventive and therapeutic activities of the extract of Ramulus Mori (ERM) to observe its effects on collagen-induced arthritis (CIA) in mice and to explore the mechanisms of ERM in the treatment of rheumatoid arthritis (RA). We examined the in vitro levels of tumor necrosis factor $\alpha$ (TNF- $\alpha$ ) released in macrophages and of interferon (IFN)- $\gamma$ and interleukin (IL)-4 released in splenocytes. For in vivo experiments, we randomly divided 24 mice into four groups, after type II collagen (CII) injections and at euthanization. The levels of plasma cytokines (TNF- $\alpha$, IL-6, IL-17), rheumatoid factor (RF; IgG, IgM), and anti-CII antibody were measured using ELISA kits. The number of immunocytes $\left(\mathrm{CD} 4^{+} \mathrm{T}\right.$ cells, $\mathrm{CD} 3^{+} / \mathrm{CD} 69^{+} \mathrm{T}$ cells, $\mathrm{B} 220^{+} / \mathrm{CD} 45^{+} \mathrm{B}$ cells, CD11 ${ }^{+} / \mathrm{Gr}-1^{+}$cells) relative to RA was calculated using flow cytometry (FACS). The articular index (AI) was recorded once a week for 4 weeks. Sections of tissues from the knee joints were stained with hematoxylin and eosin (H\&E) and Masson trichrome (MT) after the mice with CIA were euthanized. ERM reduced the levels of TNF- $\alpha$ in macrophages and IFN- $\gamma$ in spleen cells, decreased AI scores, and improved inflammation of paw joints (PJ). ERM also suppressed the number of immunocytes in peripheral blood mononuclear cells (PBMCs) and PJ, and reduced the levels of cytokines (TNF- $\alpha$, IL-6, and IL-17), RF, and anti-CII antibody in the sera. TNF- $\alpha$ and Th1 cells play very important roles in the formation and development of RA. ERM and methotrexate notably decreased the induction of RA in the CIA mice model by reducing the levels of inflammatory cytokines and RF in the sera and suppressing the number of immunocytes among PBMCs and PJ.
\end{abstract}

Key words — Ramulus Mori, collagen-induced arthritis, rheumatoid factor, tumor necrosis factor $\alpha$, interleukin6 , peripheral blood mononuclear cell

\section{INTRODUCTION}

Rheumatoid arthritis (RA) is a "Li Jie Feng" disease, categorized as "bi-syndrome" in Chinese medicine. Symptoms include swollen and painful joints, leading to limitation in motion. The disease

\footnotetext{
${ }^{1}$ Present address: Department of Herbal Pharmaceutical Engineering, College of Herbal Bio-Industry, Daegu Haany University, 290, Yugok-dong, 1, Hanui-daero, Gyeongsan-si, 712 715, Gyeongsangbuk-do, Republic of Korea

*To whom correspondence should be addressed: Department of Herbology, College of Oriental Medicine, Daejeon University, 96-3, Yongun-dong, Dong-gu, Daejeon-si, 300-716, Republic of Korea. Tel.: +82-43-280-2640; Fax: +82-42-280-2640; Email: genin@dju.ac.kr
}

is caused by wind, cold, and dampness, which block the channels of the limbs. ${ }^{1)}$

Ramulus Mori (RM) is the dried young branch of Morus alba LiNN. (M. alba LINN.), family Moraceae. In oriental medicine, RM expels the wind and dampness that promote the development of RA in human joints. RM eradicates the pain of bi-syndrome caused by wind and dampness, especially migratory bi-syndrome in the upper limbs. RM further induces diuresis to relieve edema in the swollen joints of Li Jie Feng disease. ${ }^{2)}$

The constituents of RM include tannin, stachyose, raffinose, arabinose, xylose, mulberrin, mulberrochromene, cyclomulberrin, betulinic acid, moracin $\mathrm{A}-\mathrm{H}$, morin, dihydromorin, maclurin, 
dihydrokaempferol, oxyresveratrol, dihydrooxyresveratrol, $\alpha$-amyrin, and monosaccharides. Morin has excellent antioxidant and antiinflammatory activities and suppresses inflammation induced by macrophages. ${ }^{3-5)}$

MR has immune-adjusting, antihypertensive, antibacterial, analgesic, and antiinflammatory effects and is frequently used to treat hypertension, $\mathrm{RA}$, and diabetes. It promotes the conversion of lymphocytes associated with depressed systemic immunity. RM contains methotrexate (MTX) components, and specifically modulates cytokine production by $\mathrm{T}$ cells and macrophages in murine collagen-induced arthritis (CIA). 6,7 )

We studied the effects of RM treatment on the in vitro levels of tumor necrosis factor (TNF)- $\alpha$ secreted by macrophages, and of interferon (IFN)- $\gamma$ and interleukin (IL)- 4 secreted by $\mathrm{CD}^{+}{ }^{+} \mathrm{T}$ cells. In in vivo experiments, we estimated the anti-RA effects of RM using mice models with RA induced by type II collagen (CII).

\section{MATERIALS AND METHODS}

\section{Plant Material and Preparation of Extracts}

The aerial parts of $M$. alba LiNN. were purchased from a local market (Daejeon, Republic of Korea) in September 2009. The plant was identified by Professor Young-Bae Seo, College of Oriental Medicine, Daejeon University, Daejeon, Republic of Korea. A voucher specimen (extract of RM; ERM0709) was deposited in the Department of Herbology, College of Oriental Medicine, Daejeon University, Daejeon, Republic of Korea. To obtain a dried powdered herbal sample, M. alba LINN. was extracted separately, using a cold percolation method with methanol for $72 \mathrm{hr}$. Plant material $(300 \mathrm{~g})$ was extracted three times with distilled water (DW). The extract was filtered and evaporated on a rotary evaporator (BUCHI B-480, Buchi, Flawil, Switzerland), and then dried using a freeze dryer (EYELA FDU-540, SUNILEYELA, Tokyo, Japan) to yield ERM $(39 \mathrm{~g})$. The yield (w/w) of the extract was approximately $13 \%$.

\section{Isolation and Culture of Macrophages -}

To isolate primary macrophages, thioglycolate broth $1 \%$ was injected intraperitoneally in female C57BL/6 mice. After three days, macrophages were collected by intraperitoneal injection. Havested cells were washed once with phosphate buffered saline (PBS) solution $\left(\mathrm{Ca}^{+}\right.$and $\mathrm{Mg}^{+}$free), were cultured for $24 \mathrm{hr}$ in fetal bovine serum (FBS) $10 \%$ RPMI-1640 (Whittaker, Walkersville, MD, U.S.A.) with penicillin $100 \mathrm{U} / \mathrm{ml}$ and streptomycin (Whittaker) $100 \mu \mathrm{g} / \mathrm{ml}$. Macrophage-enriched cells were $>75 \% \mathrm{Macl}^{+}$as assessed by fluorescence activated cell sorting (FACS) analysis.

Culture of Spleen Cells-Cell cultures of splenic mononuclear cells $\left(1 \times 10^{5}\right)$ were performed in complete medium consisting of RPMI-1640 (Whittaker) supplemented with glutamine $3 \mathrm{ml}$, HEPES buffer $10 \mathrm{~mm}, 100 \mathrm{U} / \mathrm{ml}$ each of penicillin, streptomycin (Whittaker) and $10 \%$ heat-inactivated fetal calf serum (FCS). Control cells were treated with ERM $100 \mu \mathrm{g} / \mathrm{ml}$ in complete RPMI medium and cultured in coated anti-CD3 $(1 \mu \mathrm{g} / \mathrm{ml})$ 96-well costar dishes for $48 \mathrm{hr}$.

Detection of TNF- $\alpha$, IFN- $\gamma$ and IL-4 Production In Vitro - Cultured macrophages $\left(5 \times 10^{5}\right)$ were treated with ERM (50 and $100 \mu \mathrm{g} / \mathrm{ml}$ ) and lipopholysaccharide (LPS) $1 \mu \mathrm{g} / \mathrm{ml}$. Culture supernatants were harvested $24 \mathrm{hr}$ after LPS treatment. TNF- $\alpha$ production was measured using ELISA according to the manufacturer's instructions on a monoclonal antibody-based mouse ELISA kit (R\&D Systems, Minneapolis, MN, U.S.A.). IFN- $\gamma$ and IL4 production was measured using ELISA according to the manufacturer's instructions on a monoclonal antibody-based mouse ELISA kit (R\&D Systems). Animals - Male DBA/1J (ILAR codes DBA/2NTacSamfBR) mice (7-8 weeks old) were obtained from Samtaco Inc. (Seoul, Republic of Korea). All animal procedures were conducted in accordance with the guidelines of the Institutional Animal Care and Use Committee, Korean Research Institute of Bioscience and Biotechnology, Daejeon, Republic of Korea. The Institutional Review Board (IRB) number was DHU2009-15.

Preparation of CIA Mice Model — The treatment procedures for 30 mice (one normal group and four control groups) were approved by the Experimental Animal Commission of the Institute of Traditional Medicine and Bioscience, Daejeon University, Daejeon, Republic of Korea. CIA was induced in the mice (6 mice per group) using a modified version of the previous method. ${ }^{8)}$ In brief, male DBA/1J mice (7-8 weeks old) received $200 \mu \mathrm{g}$ of bovine CII (Sigma, St. Lois, MO, U.S.A.) in Freund's complete adjuvant (Sigma) by intradermal injection at the base of the tail on day 0 , followed by a booster injection on day 21 . The mice were monitored daily for signs of arthritis, and each paw was scored individually as follows: $0=$ no change; 
$1=$ significant swelling and erythema of one digit;

$2=$ swelling and erythema of two digits; $3=$ mild swelling and erythema of the limb or swelling of more than two digits; $4=$ marked swelling and erythema of the limb; and $5=$ maximal swelling and erythema of the limb and later ankylosis on flexion. Each mouse was assigned an arthritis score [articular index (AI)] equal to the sum of the scores for each paw, so that the maximum possible score per mouse was 16 . In the prophylactic dosing model, mice were orally administered ERM (200 or $100 \mathrm{mg} / \mathrm{kg}$ dissolved in DW) daily from day 1 to day 28 after the confirmation of arthritis and monitored for the incidence and severity of arthritis up to day 28. The normal mice and CIA control mice were orally administered PBS alone. In summary, the four groups were as follows: normal group; positive control group; and two vehicle groups (ERM 200 and $100 \mathrm{mg} / \mathrm{kg}$ ).

On the final day of the experiment, all of the mice were anesthetized with ethyl ether and blood was collected from each by cardiac puncture. The mice were then killed by cervical dislocation. The mice spleens, thymus glands, and lymph nodes were removed and used for an ELISA and total cell counts.

\section{Antibodies and Flow Cytometric Analysis -} We collected peripheral blood mononuclear cells (PBMCs) and paw joints (PJ) of the CIA mice. The PJ were chopped in PBS and treated with collagenase $(1 \mathrm{mg} / \mathrm{ml}$ in $2 \%$ FBS + RPMI-1640 medium) for $30 \mathrm{~min}$ at $37^{\circ} \mathrm{C}$ in a shaker culture $(180 \mathrm{rpm}$, $20 \mathrm{~min}$ ). Supernatants were collected four times as described previously.

All antibodies (CD3e-PE, CD4-FITC, Gr-1-PE, CD11b-FITC, CD28-FITC, CD45b-FITC, B220$\mathrm{PE}$, and CD69-FITC) for flow cytometry (FACS) were purchased from Becton Dickinson (BD) PharMingen (San Diego, CA, U.S.A.). Cells from the lymph nodes and spleens were stained with the indicated antibodies in staining buffer (PBS containing $1 \% \mathrm{FBS}$ and $0.01 \% \mathrm{NaN}_{3}$ ) for $10 \mathrm{~min}$ on ice and analyzed with two-color flow cytometry on a FACScan using CellQuest software (BD Biosciences, Mountain View, CA, U.S.A.). Absolute cell numbers were counted manually in a hemocytometer chamber (Fisher, Pittsburgh, PA, U.S.A.). Thereafter, $2 \times 10^{3}$ cells were spun onto glass slides (Cytospin centrifuge, Cellspin, Hanil, Seoul, Republic of Korea, $400 \mathrm{~g}$ for $4 \mathrm{~min}$ ). A differential count was made according to standard morphologic criteria. The absolute numbers of various immune cells were counted by multiplied number [the total number multiplied by the gating percentage (CD area in FACS data) in the lymph node and spleen]. ELISA — IL- 4, TNF- $\alpha$, and IFN- $\gamma$ from macrophage cultures, IL-6, anti-CII, IgG, and IgM production from mice sera $(n=6)$ were measured using ELISA according to the manufacturer's instructions, using a monoclonal antibody-based mouse interleukin ELISA kit (R\&D Systems). All data are presented as the mean (S.D.) of at least three different determinations and were compared using Student's $t$-test.

Staining of Knee Joints in the Murine CIA Induced RA Model — For histologic analysis of the knee joints, the hind limbs of the mice were removed postmortem, fixed in $10 \%$ neutral-buffered formalin, decalcified in 5\% formic acid, and embedded in paraffin. Tissue sections were stained with hematoxylin and eosin $(\mathrm{H} \& \mathrm{E})$ or Masson trichrome (MT).

Statistical Analysis — For statistical analysis of data, $p$ values were analyzed using a paired Student's $t$-test software program (Startview 5.1; Abacus Concepts, Berkeley, CA, U.S.A.). The results were considered statistically significant at ${ }^{*} p<$ $0.05,{ }^{* *} p<0.01$, and ${ }^{* * *} p<0.001$.

\section{RESULTS}

\section{In Vitro Levels of TNF- $\alpha$}

The level of TNF- $\alpha$ in the culture supernatant of macrophages treated with LPS $1 \mu \mathrm{g} / \mathrm{ml}$ was $421.2 \pm 10.8 \mathrm{pg} / \mathrm{ml}$, which was higher than that in the culture supernatant of normal macrophages (Fig. 1). In contrast, the levels of TNF- $\alpha$ in the culture supernatant of macrophages treated with ERM at 100 and $50 \mathrm{mg} / \mathrm{kg}$ were $293.7 \pm 9.5$ and $388.4 \pm 32.4 \mathrm{pg} / \mathrm{ml}$, respectively, which were significantly lower than that in the culture supernatant of normal macrophages $\left({ }^{*} p<0.05,{ }^{* *} p<0.01\right)$.

The level of IFN- $\gamma$ in the culture supernatant of splenocytes treated with anti-CD3 antibody $1 \mu \mathrm{g} / \mathrm{ml}$ and anti-CD28 antibody $1 \mu \mathrm{g} / \mathrm{ml}$ was $310.4 \pm 29.4 \mathrm{pg} / \mathrm{ml}$, which was higher than that of the control (Fig. 2). In contrast, the level of IFN- $\gamma$ in the culture supernatant of splenocytes treated with ERM $100 \mathrm{mg} / \mathrm{kg}$ was $293.4 \pm 41.0 \mathrm{pg} / \mathrm{ml}$, which was significantly lwer than that of the control $\left({ }^{* *} p<0.01\right)$.

The level of IL-4 in the culture supernatant of splenocytes treated with anti-CD3 antibody 


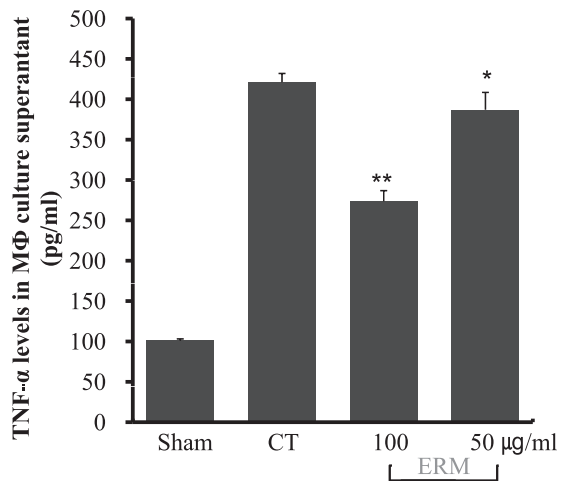

Fig. 1. Changes in LPS-induced Production of TNF- $\alpha$ in Macrophages Treated with ERM

Primary macrophages were incubated with ERM in the presence of LPS $1 \mu \mathrm{g} / \mathrm{ml}$ for $24 \mathrm{hr}$. The levels of TNF- $\alpha$ were measured using ELISA. Normal control, culture supernatant of macrophages in normal DBA/1OlaHsd mice; CII, culture supernatant of macrophages treated with LPS $1 \mu \mathrm{g} / \mathrm{ml}$; ERM, culture supernatant of macrophages treated with LPS $1 \mu \mathrm{g} / \mathrm{ml}$ and ERM 100 or $50 \mathrm{mg} / \mathrm{kg}$. The results are expressed as mean (S.D., $n=6$ ). Comparisons among control and test groups were analyzed using Student's $t$-test; ${ }^{*} p<0.05$ and ${ }^{* *} p<0.01$ compared with the control.

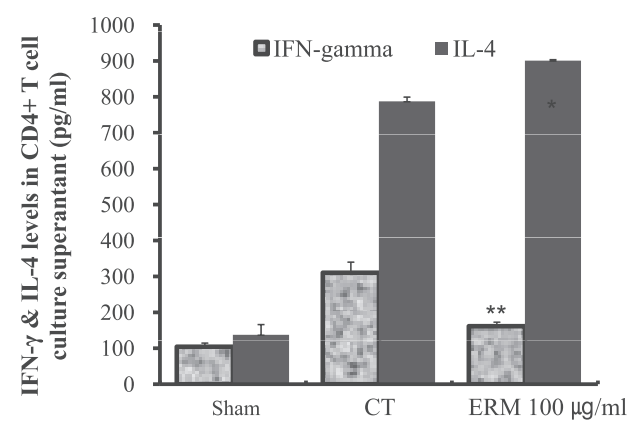

Fig. 2. Changes in IFN- $\gamma$ and IL-4 Production in the Culture Supernatants of Splenocytes Stimulated with Anti-CD3 and Anti-CD28 Antibodies and Treated with ERM

Splenocytes were stimulated with anti-CD3 and anti-CD28 antibodies and incubated with ERM for two days. The levels of IFN$\gamma$ and IL-4 in the culture supernatant were determined using a commercially available ELISA kit. Normal control, culture supernatant of CD3/CD28 nonstimulated splenocytes; CT, culture supernatant of splenocytes treated with anti-CD3 antibody $1 \mu \mathrm{g} / \mathrm{ml}$ and anti-CD28 antibody $1 \mu \mathrm{g} / \mathrm{ml}$; ERM 100 , culture supernatant of splenocytes treated with anti-CD3 antibody $1 \mu \mathrm{g} / \mathrm{ml}$, anti-CD28 antibody $1 \mu \mathrm{g} / \mathrm{ml}$, and ERM $100 \mu \mathrm{g} / \mathrm{ml}$. The results are expressed as mean (S.D., $n=6$ ). Comparisons among control and test groups were analyzed using Student's $t$-test; ${ }^{* *} p<0.01$ compared with control.

$1 \mu \mathrm{g} / \mathrm{ml}$ and anti-CD28 antibody $1 \mu \mathrm{g} / \mathrm{ml}$ was $787.4 \pm 12.0 \mathrm{pg} / \mathrm{ml}$, which was higher than that of the control (Fig. 2). In contrast, the level of IL-4 in the culture supernatant of splenocytes treated with ERM $100 \mathrm{mg} / \mathrm{kg}$ was $896.4 \pm 4.7 \mathrm{pg} / \mathrm{ml}$, which was significantly lower than that of the control $\left({ }^{*} p<0.05\right)$.

\section{In Vivo Changes in the AI}

To determine whether ERM suppresses the immune-mediated pathologic process in arthritic mice, we investigated the effect of ERM on the arthritis incidence and AI scores of CIA in DBA/1 J mice. The AI scores of the groups treated with MTX and ERM $(200 \mathrm{mg} / \mathrm{kg}, 100 \mathrm{mg} / \mathrm{kg})$ were significantly lower than that of the control group. The control AI score continued to increase until the end of the experiment. The AI scores of the groups treated with MTX and ERM were monitored regularly for 2 weeks, until the mice were killed. From 1-4 weeks after treatment with ERM $(200 \mathrm{mg} / \mathrm{kg}$, $100 \mathrm{mg} / \mathrm{kg}$ ), beginning 1 day after the booster injection of collagen, the incidence, AI score and severity of CIA were significantly suppressed $\left({ }^{*} p<0.05\right.$, ${ }^{* *} p<0.01$, Fig. 3). A similar effect was observed during the three weeks of treatment with ERM, during which a significant inhibition of arthritis progression ${ }^{* *} p<0.01$ ) was apparent (Fig. 3).

\section{Changes in the Number of Immune Cells in PBMCs}

To evaluate the efficacy of ERM treatment on $\mathrm{CD}^{+} \mathrm{T}$ cell, $\mathrm{CD}^{+} / \mathrm{CD}^{+} 9^{+} \mathrm{T}$ cell, and $\mathrm{B} 220^{+} / \mathrm{CD} 45^{+} \mathrm{B}$ cell populations in PBMCs, we compared the effects of ERM on the expression of intracellular $\mathrm{CD}^{+} \mathrm{T}$ cells, $\mathrm{CD}^{+} / \mathrm{CD}^{+} 9^{+} \mathrm{T}$ cells, and $\mathrm{B} 220^{+} / \mathrm{CD} 45^{+} \mathrm{B}$ cells in a CIA mice model by means of flow cytometry. The absolute numbers of $\mathrm{CD}^{+} \mathrm{T}$ cells, $\mathrm{CD}^{+} / \mathrm{CD}^{+} 9^{+} \mathrm{T}$ cells, and $\mathrm{B} 220^{+} / \mathrm{CD} 45^{+} \mathrm{B}$ cells in PBMCs treated with ERM $(200 \mathrm{mg} / \mathrm{kg}, 100 \mathrm{mg} / \mathrm{kg}$ ) were lower than those of the CIA control (Fig. 4).

\section{Changes in the Number of Immune Cells in PJ}

To evaluate the efficacy of ERM treatment on $\mathrm{CD}^{+} / \mathrm{CD} 9^{+} \mathrm{T}$ cell, B220 ${ }^{+} / \mathrm{CD} 45^{+} \mathrm{B}$ cell, and $\mathrm{CD} 11 \mathrm{~b}^{+} / \mathrm{Gr}-1^{+}$cell populations in $\mathrm{PJ}$, we compared the effects of ERM on the expression of intracellular $\mathrm{CD}^{+} / \mathrm{CD} 69^{+} \mathrm{T}$ cells, B $220^{+} / \mathrm{CD} 45^{+} \mathrm{B}$ cells, and $\mathrm{CD} 11 \mathrm{~b}^{+} / \mathrm{Gr}-1^{+}$cells in a CIA mice model by means of flow cytometry.

The absolute numbers of $\mathrm{CD}^{+} / \mathrm{CD} 9^{+} \mathrm{T}$ cells, $\mathrm{B} 220^{+} / \mathrm{CD} 45^{+} \mathrm{B}$ cells, and $\mathrm{CD} 11 \mathrm{~b}^{+} / \mathrm{Gr}-1^{+}$cells in PJ treated with ERM $(200 \mathrm{mg} / \mathrm{kg}, 100 \mathrm{mg} / \mathrm{kg})$ were lower than those in the CIA control (Fig. 5).

\section{Changes in the Levels of Cytokines in Serum}

As shown in Fig. 6, the levels of TNF- $\alpha$, IL6 , and IL-17 in the serum were suppressed by ERM. These results support the conclusion that 

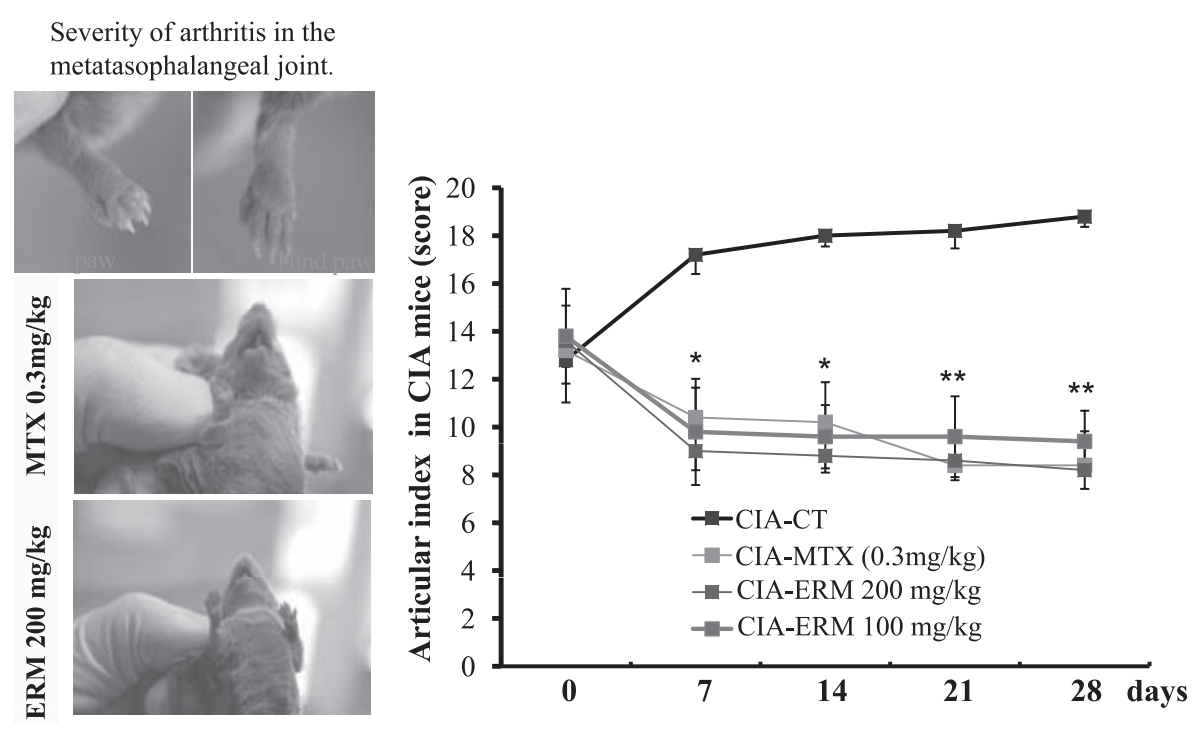

Fig. 3. Inhibitory Effects on the AI Score of PJ in CIA Mice Treated with ERM

AI scores were recorded every 7 days according to the Mann-Whitney U-test. After the second booster injection of CII, mice were divided into four groups. Each group was treated with DW, ERM, or MTX. CT, DBA/1OlaHsd mice boosted with CII $1 \mu \mathrm{g} / \mathrm{ml}$; MTX, DBA/1OlaHsd mice boosted with CII $1 \mu \mathrm{g} / \mathrm{ml}$ and treated with MTX $0.3 \mathrm{mg} / \mathrm{kg}$ three times per week for 4 weeks; ERM, DBA/1OlaHsd mice boosted with CII $1 \mu \mathrm{g} / \mathrm{ml}$ and orally treated with ERM 200 or $100 \mathrm{mg} / \mathrm{kg}$ once a day for four weeks. The results are expressed as mean (S.D., $n=6$ ). Comparisons among control and test groups were analyzed using Student's $t$-test; ${ }^{*} p<0.05,{ }^{* *} p<0.01$ compared with the control.
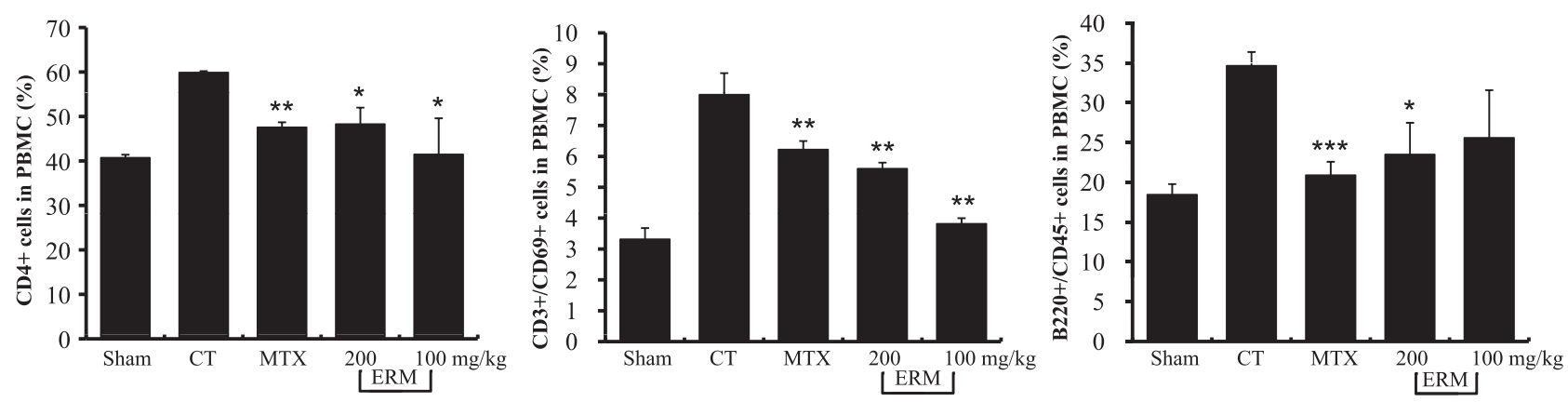

Fig. 4. Change in Absolute Numbers of $\mathrm{CD} 4^{+} \mathrm{T}$ Cells, $\mathrm{CD} 3^{+} / \mathrm{CD} 69^{+} \mathrm{T}$ Cells, and $\mathrm{B} 220^{+} / \mathrm{CD} 45^{+} \mathrm{B}$ Cells in PBMCs of CIA Mice Treated with ERM

PBMCs were isolated following 4-week administration of MTX and ERM. Sham, Normal DBA/1OlaHsd mouse group; CT, DBA/1OlaHsd mouse group boosted with CII $1 \mu \mathrm{g} / \mathrm{ml}$; MTX, DBA/1OlaHsd mouse group boosted with CII $1 \mu \mathrm{g} / \mathrm{ml}$ and treated with MTX $0.3 \mathrm{mg} / \mathrm{kg}$ three times a week for four weeks; ERM, DBA/1OlaHsd mouse group boosted with CII $1 \mu \mathrm{g} / \mathrm{ml}$ and orally treated with ERM $200 \mathrm{or} 100 \mathrm{mg} / \mathrm{kg}$ once a day for four weeks. The results are expressed as mean (S.D., $n=6$ ). Comparisons among control and test groups were analyzed using Student's $t$-test; ${ }^{*} p<0.05,{ }^{* *} p<$ 0.01 and $^{* * *} p<0.001$ compared with the control.

ERM suppresses the generation of proinflammatory cytokines, including IL- 6 and TNF- $\alpha$, comparable to the RA control $\left({ }^{*} p<0.05,{ }^{* *} p<0.01,{ }^{* * *} p<\right.$ 0.001 ).

\section{Changes in the Level of Rheumatoid Factor (RF)}

RFs are naturally occurring autoantibodies with specificity for the Fc region of IgG. There are two basic types of RF. The first is the low-affinity type that is produced in a $\mathrm{T}$ cell-independent manner, is of the IgM class, and is thought to facilitate immune complex removal by the reticuloendothelial system.
The second type is of the high-affinity type and can comprise isotypes other than $\operatorname{IgM}$, such as $\operatorname{IgG}, \operatorname{IgA}$, or IgE. The diagnosis of RA can be made using RFs, including IgG and IgM. As shown in Fig. 7, the levels of IgG, IgM, and anti-CII antibody in the serum were significantly suppressed by ERM to levels comparable to the RA control $\left({ }^{*} p<0.05,{ }^{* *} p<\right.$ $\left.0.01,{ }^{* * *} p<0.001\right)$.

\section{Histologic Analysis}

The infiltration of immune cells and synovial cells was severe in CIA control mice (Fig. 8E and 

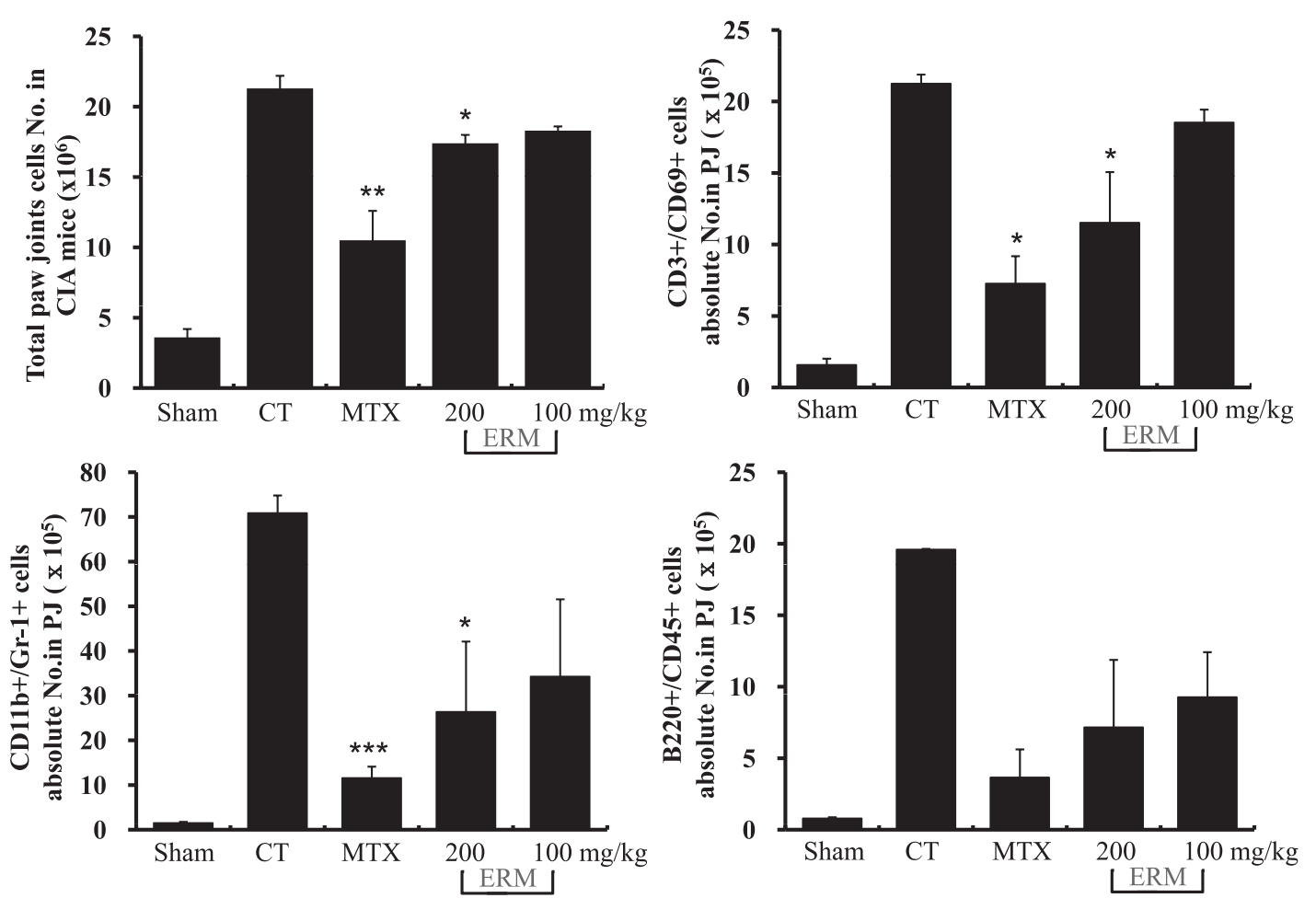

Fig. 5. Change in Absolute Numbers of $\mathrm{CD}^{+} / \mathrm{CD} 69^{+} \mathrm{T}$ Cells, $\mathrm{B} 220^{+} / \mathrm{CD} 45^{+} \mathrm{B}$ Cells, and $\mathrm{CD} 11 \mathrm{~b}^{+} / \mathrm{Gr}-1^{+}$Cells of PJ Tissues in CIA Mice Treated with ERM

PJ tissue cells $\left(1 \times 10^{5}\right.$ cell $\left./ \mathrm{ml}\right)$ were isolated following 4-week administration of MTX and ERM. PJ tissue cells were incubated with Fluorescein isothiocyanate (FITC)-conjugated anti-CD3 $3^{+} / \mathrm{CD} 69^{+}$, anti-B220 $/ \mathrm{CD} 45^{+}$, and anti-CD11b ${ }^{+} / \mathrm{Gr}-1^{+}$antibodies and analyzed using a flow cytometer. The results are expressed as mean (S.D., $n=6$ ). Comparisons among control and test groups were analyzed using Student's $t$-test; ${ }^{*} p<0.05,{ }^{* *} p<$ 0.01 and $^{* * *} p<0.001$ compared with the control.

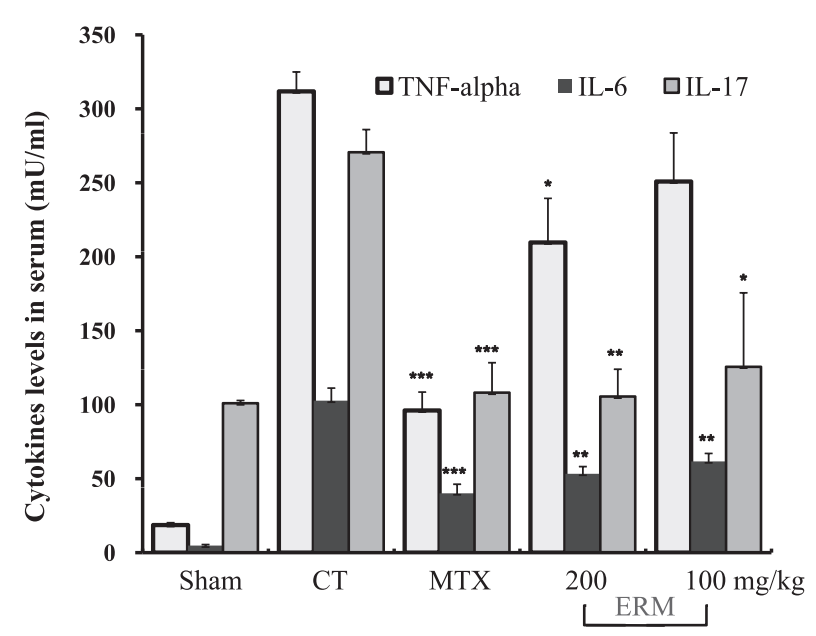

Fig. 6. Change in TNF- $\alpha$, IL-6, and IL-17 Cytokine Production in Serum of CIA Mice Treated with ERM

Blood was collected from individual mice after 4-week administration of MTX and ERM. Blood was collected from the retroorbital plexus under ether anesthesia, and serum was obtained by $10000 \mathrm{rpm}$ centrifugation and stored at $-20^{\circ} \mathrm{C}$ until use. The levels of TNF- $\alpha$, IL6 , and IL-17 were determined using a commercially available ELISA kit. The results are expressed as mean (S.D., $n=6$ ). Comparisons among control and test groups were analyzed using Student's $t$-test; ${ }^{*} p<0.05,{ }^{* *} p<0.01$ and ${ }^{* * *} p<0.001$ compared with the control.
8 F). However, ERM $200 \mathrm{mg} / \mathrm{kg}$ substantially reduced the severity of the disease (Fig. $8 \mathrm{M}$ and $8 \mathrm{~N}$ ). A slight increase in synovial cell infiltration was detected in the joints of animals receiving of ERM $100 \mathrm{mg} / \mathrm{kg}$ (Fig. 8), but no discernible cartilage erosion was observed in the knee joints of these animals. These histopathologic results suggest that ERM suppresses the immune-mediated pathologic process in the CIA mice model.

We orally inoculated ERM $(100 \mathrm{mg} / \mathrm{kg}$, $200 \mathrm{mg} / \mathrm{kg}$ ) into CIA mice for four weeks to determine whether ERM prevented articular destruction. At the end of the experiment, we histologically analyzed the knee joints of mice using H\&E and MT staining.

Normal mice had clear articular cavities and showed no erosion of bone and cartilage, no deposition of collagen, and no infiltration of inflammatory cells (Fig. 8C and 8D). In contrast, CIA control mice (induced by CII injection) showed subsynovial inflammation due to macrophages, granulocytes, mononuclear cells, and fibrocytes. Moreover, invasion of the hyperplasia by synoviocytes caused 

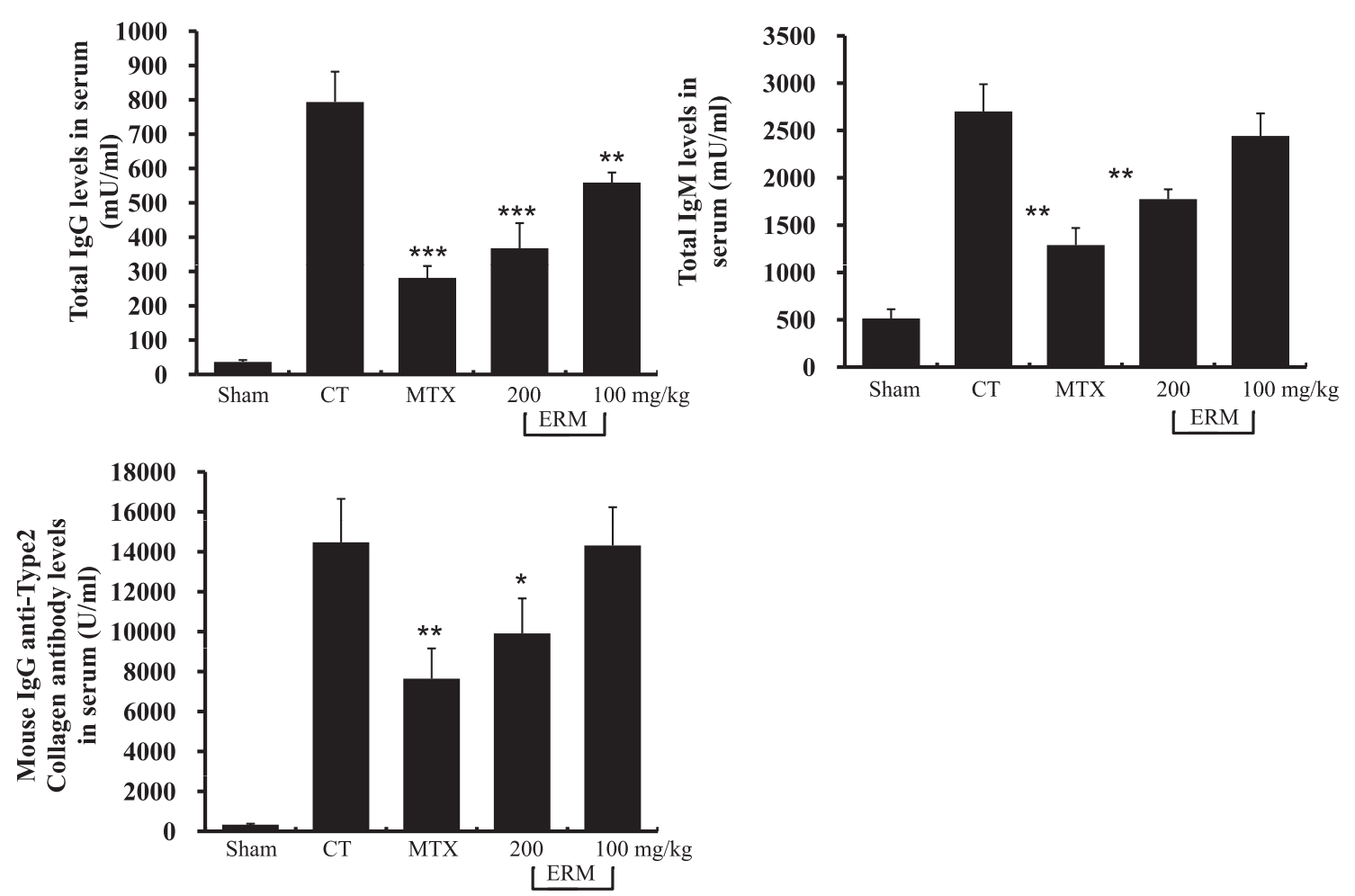

Fig. 7. Change in Levels of Total IgG, IgM, and IgG Anti-CII Antibody in Serum of CIA Mice Treated with ERM

Blood was collected from individual mice after 4-week administration of MTX and ERM. Blood was collected from the retroorbital plexus under ether anesthesia, and serum was obtained by $10000 \mathrm{rpm}$ centrifugation and stored at $-20^{\circ} \mathrm{C}$ until use. The levels of IgG, IgM, RF and IgG anti-CII antibody were determined using a commercially available ELISA kit. The results are expressed as mean (S.D., $n=6)$. Comparisons among control and test groups were analyzed using Student's $t$-test; ${ }^{*} p<0.05,{ }^{* *} p<0.01$ and ${ }^{* * *} p<0.001$ compared with the control.

the erosion of bone and cartilage (Fig. $8 \mathrm{G}$ and $8 \mathrm{H}$ ). Destruction of the synovium, vasodilation, and the cartilage pannus junction was observed.

MTX and ERM administered at concentrations of $0.3,200$, and $100 \mathrm{mg} / \mathrm{kg}$ substantially reduced the severity of the disease. A small increase in synovial cell infiltration was detected in the joints of animals receiving ERM $100 \mathrm{mg} / \mathrm{kg}$, but no discernible cartilage erosion was observed in the knee joints of these animals. Treatment with ERM $200 \mathrm{mg} / \mathrm{kg}$ was more effective than treatment with ERM $100 \mathrm{mg} / \mathrm{kg}$ in alleviating the symptoms of the disease. These histopathologic results suggest that ERM suppresses the Th1-mediated pathologic process in the CIA mice model.

\section{DISCUSSION}

RA is an autoimmune disease that involves multiple arthritic inflammation, caused by the many cytokines released by immunocytes, protease, destruction of bones, and loss of cartilage due to pan- nus. The disease is characterized by chronic and hypertrophic synovial membranes and numerous inflammatory processes in the cavum articulare. RA causes edema and joint pain during the early period of disease, diagnostic aberrant and ankylosis of articulation in more progressive cases. ${ }^{9)}$

A specific pathologic feature of RA is continuous active synovitis that invades a terminal movable joint. The inflammagen induces the infiltration into synovial joints of $\mathrm{CD} 4^{+} \mathrm{T}$ cells, macrophages, and plasma cells. ${ }^{10,11)}$

In previous studies, $M$. alba LINN. exerted antiinflammatory effects on activated macrophages, ${ }^{5,12)}$ through suppression of nuclear factor $\kappa$ B-regulated Ge. ${ }^{13)}$ To investigate the effect of ERM on CIA in mice, we studied the in vitro formation of TNF- $\alpha$ released in macrophages and the formation of IFN- $\gamma$ and IL- 4 released in Th cells. The anti-RA effects of $\mathrm{RM}$ was investigated using a CIA mice model and the results were analyzed by means of FACS assay, ELISA, histopathologic analysis, and AI scores in vivo.

TNF- $\alpha$ is a direct inflammatory mediator, 

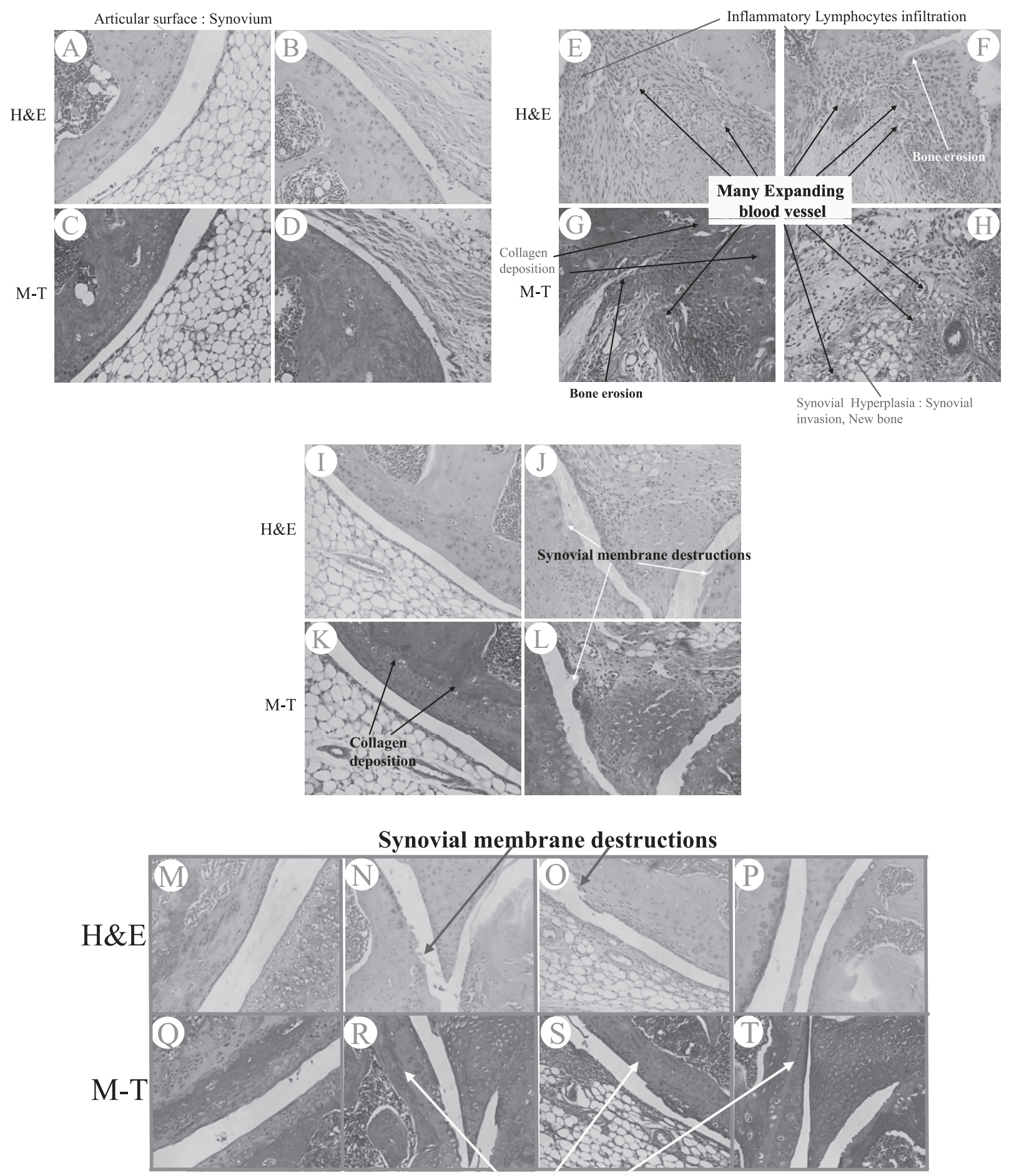

Collagen deposition

Fig. 8. Histologic Changes in PJ Tissue in CIA Mice Treated with ERM

DBA/1OlaHsd mice were killed, their hind limbs were removed, and the paws were processed for histology and stained with H\&E and M-T staining. Control, CIA mice were analyzed histopathologically. Intraarticular exudate, marginal erosion, necrotic chondrocytes, and relative loss of proteoglycans in the articular cartiage are shown. Original magnification $\times 200$. A, B, PJ tissues stained with H\&E in CIA DBA/1OlaHsd mice; C, D, PJ tissues stained with M-T in CIA DBA/1OlaHsd mice; E, F, PJ tissues stained with H\&E in CIA DBA/1OlaHsd mice; G, H, PJ tissues stained with M-T in CIA DB/1OlaHsd mice; I, J, PJ tissues stained with H\&E in CIA DBA/1OlaHsd mice treated with MTX $0.3 \mathrm{mg} / \mathrm{kg} ; \mathrm{K}, \mathrm{L}, \mathrm{PJ}$ tissues stained with M-T in CIA DBA/1OlaHsd mice treated with MTX $0.3 \mathrm{mg} / \mathrm{kg} ; \mathrm{M}, \mathrm{N}, \mathrm{PJ}$ tissues stained with H\&E in CIA DBA/1OlaHsd mice treated with ERM $200 \mathrm{mg} / \mathrm{kg}$; O, P, PJ tissues stained with H\&E in CIA DBA/1OlaHsd mice treated with ERM $100 \mathrm{mg} / \mathrm{kg}$; Q, R, PJ tissues stained with M-T in CIA DBA/1OlaHsd mice treated with ERM $200 \mathrm{mg} / \mathrm{kg} ; \mathrm{S}, \mathrm{T}$, PJ tissues stained with M-T in CIA DBA/1OlaHsd mice treated with ERM $100 \mathrm{mg} / \mathrm{kg}$. 
which works in conjunction with IL-1, granulocyte macrophage colony-stimulating factor, IL-6, and IL-8. ${ }^{10)}$ The formation of pannus in articular tissue is known to arise from the stimulation of enzymes by macrophages and fibrocytes, which respond by producing proinflammatory cytokines such as matrix metalloproteinase, TNF- $\alpha$, and IL-1 in the inner synovial membrane. TNF- $\alpha$ plays an important role in the secretion of IL-1, which promotes osteoclasia and chondrolysis. ${ }^{14-16)}$

A previous study showed that TNF- $\alpha$ and IL1 accelerated the secretion of IL-6, and IL- 6 stimulated $\mathrm{B}$ cells and activated T cells and antigenpresenting cells. ${ }^{17)}$ IL-6 and IL-1 play major roles in RA by promoting bone resorption and suppressing osteogenesis. IL-6 is released by normal T cells, normal B cells, macrophages, and endotheliocytes. It was reported that an IL-6-knockout mouse was protected from bone loss induced by deficiency of estrogen and androgen. ${ }^{18-20)} \mathrm{IL}-6$, in conjunction with IL-17, TNF- $\alpha$, and IL-1, induces native $\mathrm{CD}^{+}$ $\mathrm{T}$ cells to differentiate to Th17 cells. The differentiated Th17 cells regenerate IL-6, IL-17, IL-22, and TNF- $\alpha .^{21,22)}$

A previous study showed that RA was developed by a disproportion of cytokines released by Th1 and Th2 cells (attaining superiority of Th1 cell cytokines $^{23,24)}$ in interconverting of Th cells). The formation of IFN- $\gamma$ and IL-17 leads to a deterioration in the shifting to Th2 cells, but promotes the shifting to Th1 cells. A product of IL-4 secreted by Th2 cells suppresses RA symptoms through the inhibition of IFN- $\gamma$ and IL-17 product formation. ${ }^{25)}$ In our in vitro study, ERM significantly promoted the production of IL-4 and inhibited the production of TNF- $\alpha$ and IFN- $\gamma$ compared with the CIA control. It appears that ERM inhibited the interconverson of Th cells and strongly inhibited the conversion of native $\mathrm{CD} 4^{+} \mathrm{T}$ cells into Th1 cells.

We orally administered CIA mice ERM at concentrations of 200 and $100 \mathrm{mg} / \mathrm{kg}$ for four weeks to study the preventive and therapeutic effects of ERM based on AI scores and clinical signs, FACS analysis of PBMCs and PJ, ELISA analysis of serum, and histopathologic analysis of PJ. The AI scores were similar to those of the histologic analysis. The CIA mice treated with ERM did not show an increase in disease severity in terms of microangiopathy, tissue edema, proliferation of synovial cells, infiltration of lymphocytes, or erosion of bones in joints treated with MTX and ERM. Analysis of PBMC immune cells showed that the numbers of $\mathrm{CD} 4^{+} \mathrm{T}$ cells and
$\mathrm{B} 220^{+} / \mathrm{CD} 45^{+}$cells (activated B cells) in the CIA control group were significantly higher than those in the normal control group. Treatment with MTX and ERM $(200,100 \mathrm{mg} / \mathrm{kg})$ significantly reduced the number of $\mathrm{CD}^{+} \mathrm{T}$ cells and $\mathrm{B} 220^{+} / \mathrm{CD} 45^{+}$cells.

$\mathrm{CD}^{+} / \mathrm{CD} 69^{+} \mathrm{T}$ cells activate $\mathrm{T}$ cells via $\mathrm{CII}$ and are important indicators of CIA. The numbers of $\mathrm{CD}^{+} / \mathrm{CD} 9^{+} \mathrm{T}$ cells in PBMCs and PJ in the CIA control group were significantly higher than those in the normal control group, and it has been reported that $\mathrm{CD}^{+} \mathrm{T}$ cells and $\mathrm{CD} 11 \mathrm{~b}^{+} / \mathrm{Gr}-1^{+}$cells infiltrate the articular erosion region. Our data showed a significant decrease in the number of $\mathrm{CD}^{+} \mathrm{T}$ cells and $\mathrm{CD}_{11} \mathrm{~b}^{+} / \mathrm{Gr}-1^{+}$cells in this region.

$\mathrm{RF}$ is an autoantibody produced with specificity for the Fc region of $\mathrm{IgG}$ secreted by B cells. Hypersecretion of RF in serum is related to the severity and systemicity of RA because IFN- $\gamma$ produced by activated spleen cells and IgG2a antibodies specifically responds to collagen and is amplified in cases of severe arthritis. ${ }^{26)}$ It is thought that a reduction in RF levels will lead to an improvement of disease symptoms.

Using ELISA analysis, we compared the decreases of IL-6, IL-17, and TNF- $\alpha$ in the serum of mice treated with ERM with those in the serum of normal control mice. TNF- $\alpha$, IL-6 and IL-17 play central roles in the maintenance of chronic inflammation and tissue damage during the progression of RA. The levels of IgG, IgM and anti-CII in the serum of CIA control mice were significantly higher than those in the serum of normal control mice. Meanwhile, those in the serum of ERMtreated mice were significantly lower than those in the serum of CIA control mice.

ERM inhibited the activity of $\mathrm{CD}^{+} / \mathrm{CD} 9^{+} \mathrm{T}$ cells and macrophages, reduced the production of TNF- $\alpha$ and IL- 6 , and decreasedthe activity of natural killer $\mathrm{T}$ (NKT) cells (thus breaking the balance between Th1 T cells and Th2 T cells and stimulating $\mathrm{B}$ cells). ERM also reduced the levels of IL6 , which suggests that it inhibited the differentiation of B cells, suppressed the release of RFs, and reduced the destruction of bones and cartilage (as in the AI and histologic studies). IL-6 is crucial for the transformation of native $\mathrm{CD} 4^{+} \mathrm{T}$ cells into Th17 $\mathrm{T}$ cells, ${ }^{27)}$ a process that also involves TNF$\alpha$. This suggests that ERM reduces the production of TNF- $\alpha$ and IL-6, thus down-regulating Th17 T cells and inhibiting the release of IL-17, IL-22, and TNF- $\alpha$ produced by Th17 T cells in the serum of CIA mice. It was reported that the constituents of 
RM possess antiinflammatory and antioxidant parmacologic activities. ${ }^{3-5)}$ We suggest that some of these components may have a synergistic effect on CIA. Further research is needed to determine which fractional extraction of ERM is most effective in CIA mice. It was reported that resveratrol (a compound of $M$. alba) inhibited extracellular signalregulated kinase and p38 MAPK phosphorylation, $\mathrm{I}-\kappa \mathrm{B}-\alpha$ degradation, nerve factor $-\kappa \mathrm{B}$ activation, and cyclooxygenase- 2 expression. ${ }^{13)}$ This suggests that resveratrol inhibits IL-8 secretion by blocking MAPK phosphorylation and nerve factor- $\kappa$ B activation. Thus, MRE may inhibit nerve factor $-\kappa \mathrm{B}$ activation and cyclooxygenase- 2 expression.

\section{REFERENCES}

1) Xie, Z. and Huang, X. (1984) Dictionary of Traditionary Chinese Medicine, The Commercial Press, Beijing, p.320.

2) Tang, D. and Xun, J. (2003) Science of Chinese Material Medica, Shanghai University of Traditional Chinese Medicine, Shanghai, pp.139-142.

3) Gálvez, J., Coelho, G., Crespo, M. E., Cruz, T., Rodríguez, M. E., Concha, A. and Gonzalez, M. (2001) Intestinal anti-inflammatory activity of morin on chronic experimental colitis in the rat. $\mathrm{Al}$ iment. Pharmacol. Ther., 15, 2027-2039.

4) Wang, L., Tu, Y.-C., Lian, T.-W., Hung, J.-T., Yen, J.-H. and Wu, M.-J. (2006) Distinctive antioxidant and antiinflammatory effects of flavonols. $J$. Agric. Food Chem., 54, 9798-9804.

5) Fang, S. H., Hou, Y. C., Chang, W. C., Hsiu, S. L., Lee Chao, P. D. and Chiang, B. L. (2003) Morin sulfates/glucuronides exert anti-inflammatory activity on activated macrophages and decreased the incidence of septic shock. Life Sci., 74, 743-756.

6) Hong, S. S., Jin, M. J. and Han, H. K. (2008) Enhanced systemic availability of methotrexate in the presence of morin in rats. Biopharm. Drug Dispos., 29, 189-193.

7) Neurath, M. F., Hildner, K., Becker, C., Schlaak, J. F., Barbulescu, K., Germann, T., Schmitt, E., Schirmacher, P., Haralambous, S., Pasparakis, M., Meyer Zum Büschenfelde, K. H., Kollias, G. and Märker-Hermann, E. (1999) Methotrexate specifically modulates cytokine production by $\mathrm{T}$ cells and macrophages in murine collagen-induced arthritis (CIA): a mechanism for methotrexate-mediated immunosuppression. Clin. Exp. Immunol., 115, 42-55.

8) Lee, S. I., Hyun, P. M., Kim, S. H., Kim, K. S., Lee, S. K., Kim, B. S., Maeng, P. J. and Lim, J. S.
(2005) Suppression of the onset and progression of collagen-induced arthritis by chebulagic acid screened from a natural product library. Arthritis Rheum., 52, 345-353.

9) Schenck, P., Schneider, S., Miehlke, R. and Prehm, P. (1995) Synthesis and degradation of hyaluronate by synovia from patients with rheumatoid arthritis. J. Rheumatol., 22, 400-405.

10) Feldmann, M., Brennan, F. M. and Maini, R. N. (1996) Rheumatoid arthritis. Cell, 85, 307-310.

11) Wolfe, F. and Hawley, D. J. (1998) The longterm outcomes of rheumatoid arthritis: work disability: a prospective 18 year study of 823 patients. $J$. Rheumatol., 25, 2108-2117.

12) Chung, K. O., Kim, B. Y., Lee, M. H., Kim, Y. R., Chung, H. Y., Park, J. H. and Moon, J. O. (2003) In-vitro and in-vivo anti-inflammatory effect of oxyresveratrol from Morus alba L. J. Pharm. Pharmacol., 55, 1695-1700.

13) Manna, S. K., Aggarwal, R. S., Sethi, G., Aggarwal, B. B. and Ramesh, G. T. (2007) Morin (3,5,7,2', $4^{\prime}$-Pentahydroxyflavone) abolishes nuclear factor-kappaB activation induced by various carcinogens and inflammatory stimuli, leading to suppression of nuclear factor-kappaB-regulated Ge. Clin. Cancer Res., 13, 2290-2297.

14) Saxne, T., Palladino, M. A., Jr., Heinegard, D., Talal, N. and Wollheim, F. A. (1988) Detection of tumor necrosis factor alpha but not tumor necrosis factor beta in rheumatoid arthritis synovial fluid and serum. Arthritis Rheum., 31, 1041-1045.

15) Hopkins, S. J., Humphreys, M. and Jayson, M. I. (1988) Cytokines in synovial fluid. The presence of biologically active and immunoreactive IL-1. Clin. Exp. Immunol., 72, 422-427.

16) Brennan, F. M., Chantry, D., Jackson, A., Maini, R. and Feldmann, M. (1989) Inhibitory effect of TNF antibodies on synovialcell interleukin-1 production in rheumatoid arthritis. Lancet, 2, 244-247.

17) Takemura, S., Klimiuk, P. A., Braun, A., Goronzy, J. J. and Weyand, C. M. (2001) T cell activation in rheumatoid synovium is B cell dependent. $\mathrm{J}$. Immunol., 167, 4710-4718.

18) Roodman, G. D. (1992) Interleukin-6: an osteotrophic factor? J. Bone Miner. Res., 7, 475-478.

19) Poli, V., Balena, R., Fattori, E., Markatos, A., Yamamoto, M., Tanaka, H., Ciliberto, G., Rodan, G. A. and Costantini, F. (1994) Interleukin-6 deficient mice are protected from bone loss caused by estrogen depletion. EMBO J., 13, 1189-1196.

20) Bellido, T., Jilka, R. L., Boyce, B. F., Girasole, G., Broxmeyer, H., Dalrymple, S. A., Murray, R. and Manolagas, S. C. (1995) Regulation of interleukin- 
6 , osteoclastogenesis, and bone mass by androgens. The role of the androgen receptor. J. Clin. Invest., 95, 2886-2895.

21) Gerard, E., Kaiko, J., Horvat, C., Beagley, K. W. and Hansbro, P. M. (2008) Immunological decisionmaking: how does the immune system decide to mount a helper T-cell response? Immunology, 123, 326-338.

22) Liang, S. C., Tan, X. Y., Luxenberg, D. P., Karim, R., Dunussi-Joannopoulos, K., Collins, M. and Fouser, L. A. (2006) Interleukin (IL)-22 and IL-17 are coexpressed by Th17 cells and cooperatively enhance expression of antimicrobial peptides. J. Exp. Med., 203, 2271-2279.

23) Panayi, G. S. (1997) T-cell-dependent pathways in rheumatoid arthritis. Curr. Opin. Rheumatol., 9, 236-240.

24) Manetti, R., Parronchi, P., Giudizi, M. G., Piccinni, M. P., Maggi, E., Trinchieri, G. and Romagnani, S. (1993) Natural killer cell stimulatory factor (NKSF/IL-12) induces Th1-type specific im- mune responses and inhibits the development of IL4 producing Th cells. J. Exp. Med., 177, 1199-1204.

25) Morgan, M. E., Flierman, R., van Duivenvoorde, L. M., Witteveen, H. J., van Ewijk, W., van Laar, J. M., de Vries, R. R. and Toes, R. E. (2005) Effective treatment of collagen-induced arthritis by adoptive transfer of CD25 regulatory T cells. Arthritis Rheum., 52, 2212-2221.

26) Germann, T., Szeliga, J., Hess, H., Storkel, S., Podlaski, F. J., Gately, M. J., Schmitt, E. and Rude, E. (1995) Administration of interleukin 12 in combination with type II collagen induces severe arthritis in DBA/1 mice. Proc. Natl. Acad. Sci. U.S.A., 92, 4823-4827.

27) Mangan, P. R., Harrington, L. E., O’Quinn, D. B., Helms, W. S., Bullard, D. C., Elson, C. O., Hatton, R. D., Wahl, S. M., Schoeb, T. R. and Weaver, C. T. (2006) Transforming growth factor-beta induces development of the $\mathrm{T}(\mathrm{H}) 17$ lineage. Nature, 441, 231234. 